\title{
Investigating Inclusive Entrepreneurial Ecosystem through the lens of Bottom of the Pyramid (BOP) Theory: Case Study of Taobao Village in China
}

\begin{abstract}
:
Purpose-Entrepreneurial ecosystem is a frontier issue in the field of enterprise strategy and entrepreneurship. As suggested by Bottom of the Pyramid (BOP) theory, entrepreneurs from base of the pyramid can gain the benefits of economic growth by obtaining equal entrepreneurial opportunities with appropriate support and motivation. However, theoretical framework to understand the ecosystem and help the people from bottom of pyramid to benefit from ecosystem is under-researched. In this paper, based on investigation of Taobao ecosystem case study, we have developed a multi-layer framework to fill in the research gap.
\end{abstract}

Design/methodology/approach-We examine the case of taobao village and uses cross-case clustering analysis method. Data has been collected and analysed in terms of various aspects in Taobao's ecosystem, such as information and communications technology (ICT), government, entrepreneurs and supporting actors.

Findings-Findings suggest that ICTs empower people at base of pyramid and enable them to be inclusive and overcome shortcomings and environmental barriers to form emerging of entrepreneurial ecosystem. Research also indicates that evolution of entrepreneurial ecosystem presents a point-line-plane diffusion path, and co-creation to enhance inclusive entrepreneurship is realised by interaction and cooperation within social networks and integration of resources. Based on the above findings, the model of inclusive innovation ecosystem is further improved

Research limitations/implications-The significance of this study is to provide theoretical understanding on how to successfully form entrepreneurial ecosystem, by practical investigation of entrepreneurial "habitat" at bottom of the pyramid.

Keywords: Entrepreneurial ecosystem, Bottom of the pyramid, Inclusive entrepreneurship,Case study

Paper type Case study

\section{Introduction}

There are a number of entrepreneurial ecosystems, such as Silicon Valley in US and Zhongguancun in China, composed by a rich profusion of enterprises, Universities and research institutes with disruptive and emerging technologies. This kind of entrepreneurial ecosystem is easy to burst various innovative entrepreneurial activities (Du,W, 2018; Yin,2018; Adams, 2020). A thriving entrepreneurial ecosystem rarely appears in the countryside or in the disconnected agricultural community (Darwish, 2018). As a result, facilitation on inclusive entrepreneurship especially for the people at base of these ecosystems are under-researched. Bottom of the pyramid (BOP) group is simply treated as consumers rather than entrepreneurs (Prahalad, 2012; Ben Letaifa, 2015). In China, however, a large number of entrepreneurs in Taobao villages come from bottom of the pyramid. Deep investigation on Taobao ecosystem, especially its BOP group, can contribute to understanding of inclusive entrepreneurial 
ecosystems construction and in addition, offers the world a potential solution to reduce poverty (Li, 2019), as presented in this paper.

Taobao ecosystem has its unique economic and social value (Ruimei, P\&Xiaoqiang, X, 2019). It encourages people at the bottom group of the pyramid (BOP group) to start businesses by improving their income and, as a result, it promotes prosperity of the entire Chinese industry. After ten years of development from 2009 to 2019, the number of Taobao villages has gradually grown from 3 in 2009 to 4,310 in 2019, located in 25 provinces of China. In 2019, the combined annual sales of Taobao online stores exceeded 700 billion Chinese Yuan (roughly equals to 77 billion Pound Sterling), and the number of active online stores reached 2.44 million, generating more than 6.83 million jobs (Ali Research, 2019). This reflects the strong vitality of the entrepreneurial ecosystem of Taobao village. Compared with other entrepreneurial ecosystems with patent talents and venture capital (such as Silicon valley and Zhongguancun) Taobao village does not have any advantage. However, as suggested by Ali Research (2019), Taobao ecosystem has demonstrated an effective mechanism to support inclusive entrepreneurship because majority from bottom of the pyramid in Taobao ecosystem become entrepreneurs eventually.

How an entrepreneurial ecosystem relates to, influence, or inspire change in the economic fortunes of a place, fostering social and industrial transformations and transitions, is a worthy of study question (O'Connor, A et al, 2018). However, a comprehensive framework to understand the inclusive entrepreneurial ecosystem is missing in current literature. This paper aims to fill in this research gap by investigating Taobao ecosystem through the lens of BOP theory. The outline of this paper is structured as below:

Section 2 is devoted to literature review on theories of entrepreneurship ecosystem and BOP, summerised by a proposed theoretical framework on inclusive entrepreneurship ecosystem based on findings from secondary research; Section 3 discusses research design with consideration on case study selection and data collection; Empirical results on Taobao ecosystem are further discussed in Section 4. The paper is then concluded in Chapter 5 with revised theoretical framework of inclusive entrepreneurship ecosystem and suggestions for future research.

\section{Literature Review}

\section{Entrepreneurship Ecosystem}

Entrepreneurial ecosystem is increasingly concerned by academia and policy advisory community, and gradually becomes a frontier issue in the field of corporate strategy and entrepreneurship research (Cavallo, 2019). With the rapid development of entrepreneurship research cross the world, it is recognised that entrepreneurial activities are deeply influenced by the interaction of entrepreneurial environment and its relevant bodies (Feld, 2012; Manimala \& Wasdani, 2015). Entrepreneurial activity, as an output of the entrepreneurial ecosystem, is considered to be the process by which individuals create opportunities for innovation (Stam\&Spigel, 2016). There are many manifestations of these activities, such as innovative start-ups, high growth start-ups, and entrepreneurial employees (Stam, 2014). As Stam \& Spigel (2016) said in their research, entrepreneurial activity is an intermediary output of the ecosystem. These manifestations will eventually lead to new value in society as ultimate outcomes of an entrepreneurial ecosystem. Researchers also suggested accessible market, human capital and financial support are the three most important elements that affect entrepreneurial activities (Foster, 
2013; Drexler, 2014). However, despite its popularity, there is not yet a widely shared definition of entrepreneurial ecosystems amongst researchers or practitioners and framework to underpin entrepreneurship activities are vague.

In 1935, ecologist Tansley (1935) first proposed the concept of ecosystem, studying the relationship between organisms and the natural environment from a system perspective. The concept of ecosystem was introduced into the field of management by Moore (1993) and Iansiti (2004). After that, the research on the concept of entrepreneurial ecosystem is gradually refined. However, the concept has been used diversely in literature, making it rather 'chaotic' or 'fuzzy' in reality (Cavallo, 2019). In this case, Stam's (2015) definition, has been widely endorsed in literature for its comprehensive nature, since it encompasses all the key features of the entrepreneurial ecosystem (Acs et al. 2017a, 2017b). In addition, Stam's research has the merit of shifting the locus of EE's investigation to "productive" (i.e. innovative and growth-oriented) entrepreneurship, which is a key change in perspective for entrepreneurship research - typically more inclusive and wide-ranging when considering new ventures (Cavallo, 2019). Thus in this paper, we take the definite of entrepreneurial ecosystem which was proposed by Stam (2015). Stam (2015) believes that "the entrepreneurial ecosystem as a set of interdependent actors and factors coordinated in such a way that they enable productive entrepreneurship within a particular territory. "With the current trends of digital technology and globalization, some scholars still stressed the "territory"-specific dimension of an entrepreneurial ecosystem (Colombelli, 2017; Cavallo, 2018), while others scholars pointed out the development of digital technology and globalization can reduce spatial dependence of entrepreneurial ecosystem (Florida, 2017; Acs et al. 2017a, 2017b). But we can sure that the development of digital technology and the Internet provide the potential to further explore the subject field in a global view.

\section{Sustainability of Entrepreneurship Ecosystem}

Some researchers (Cohen 2006; Isenberg, 2011) believe the core of entrepreneurial ecosystem is external environment, which enables startups and mature enterprises. Cohen (2006) argues that the entrepreneurial ecosystem is a community formed by interacting subjects in a specific region, which supports and promotes innovation. Enterprises are established and developed create social and economic values in the system for sustainability purpose. Cohen (2006) proposed a sustainable entrepreneurship ecosystem model including four partnerships and a talent pool in the environment, as shown in Figure 2.1 below. He believes that participation of socioeconomic actors will drive more new enterprises to enter system and as a result contribute to the sustainable development of the entrepreneurial ecosystem (Cohen, 2006). Isenberg (2011) pointed out that startups are most likely to succeed when they are in an environment with easy access to capital, talent, infrastructure and support mechanism (e.g. government policy). This environment should encourage innovation and tolerate failure. In the module Isenberg proposed in 2011, sustainable entrepreneurial ecosystem should include six elements, as shown in Figure 2.2 below.

Vogel(2013) and Mason(2014), on the other hand, believe entrepreneurial ecosystem is a unified interactive system composed of both entrepreneurs and external environment. Vogel (2013) suggested that entrepreneurial ecosystem is an interactive community in a geographical area, which depends on each entrepreneurial subject and environmental factors (market, regulatory system, etc.). They coexist and interact to promote the establishment of new enterprises (Vogel, 2013). When an entrepreneurial ecosystem is established, it is essential to evaluated the system through three levels, i.e. 
micro-entrepreneurs, meso-organisations and macro-communities, in order to achieve sustainability goal (Vogel, 2013). Authors of the paper tend to support this argument.

\section{Gap in Entrepreneurship Ecosystem Literature}

A rich entrepreneurial ecosystem enables entrepreneurship and subsequent value creation at the regional level (Fritsch,2013; Tsvetkova,2015). At present, entrepreneurial ecosystems are distributed across the world and there are many research cases such as Silicon Valley (Adams,2020), Chicago Campus entrepreneurship ecosystem (Miller,2017), Cambridge cluster (Drofiak, A., \& Garnsey, 2019), Phoenix, Arizona (Mack \& Mayer, 2016) and Zhongguancun, China (DU, W, 2018) and so on. Few research is conducted based on a thriving entrepreneurship ecosystem in the countryside or in an agricultural community (Darwish, 2018).

In addition, existing research case studies mainly focus on high-tech entrepreneurial activities, and none of them take into consideration of people at the bottom of the pyramid as entrepreneurs. Instead, these people are treated as consumers and organisations aim to provide better goods or service to the people at the bottom of the pyramid by constructing the ecosystem. For instance, Prahalad (2012) took development of fuel furnaces in India as an example to illustrate the necessity of considering the BOP group as consumers to establish sustainable entrepreneurial ecosystem. Ben Letaifa (2015) regarded BOP group as consumers to realise value of co-creation and establish service innovation network. However, the concept of 'inclusive innovation' is to overcome institutional barriers, providing BOP entrepreneurs with fair choice opportunities to promote their endogenous ability development (Bhagwati \& Panagariya, 2013). This requires organisaions to mobilise BOP groups to form a cross-sector network of alliances or ecological system, which can help the BOP entrepreneurs with support mechanism in order to better create value, finally achieve the result of anti-poverty (Ramachandran et al., 2012).

\section{Bottom of the Pyramid (BOP) Theory}

'Bottom of the Pyramid', also called 'Base of the Pyramid', was coined in economic world to designate a form of inclusive capitalism, emphasising the role of enterprises in reducing poverty (Prahalad and Hart, 2002; Hart and London, 2005).

Since the concept was proposed, researchers have conducted a series of discussions and research. The early researchers on BOP theory focused on treating low-income population as valuable consumers, considering they account for $2 / 3$ of the world's population and having huge consuming potentials (Prahalad and Hart, 2002). However, some scholars pointed out that restrictions with people at the bottom of the pyramid on purchase are mainly from low-income rather than lack of appropriate products and services (Karnani, 2006a). Treating people at BOP as consumers will not solve poverty problems, while on the contrary it will increase the burden on the poor under some circumstances (Karnani, 2006a, 2006b). Therefore, a sustainable entrepreneurship ecosystem should consider BOP as a provider of resources and capabilities (Karnani, 2006a, 2006b). To regard low-income groups as consumers and producers can be seen as version 1.0 of BOP theory (BOP 1.0) (Pedrozo, 2015).

Along with the deepening of research, scholars realized that enterprises should include low-income groups as partners in the value chain and to embed the groups in local social and cultural environment of the ecosystem. This theory was regarded as BOP 2.0 and it was defined as "creating a shared fortune with BOP, by co-creations and co-inventions, deepening dialogue with the poor communities, 
generating shared commitment and mutual learning, combining profits with poverty. "(Hammond, 2011). The difference between BoP 1.0 and BoP 2.0 is that the theory of BoP 1.0 was aligned more within an organization's existing structure and main strategy, whereas the theory of BoP 2.0 emphasized the creation of a Research and Development (R\&D) "White Space" formalized within the corporation (Dembek et al, 2020). After that the 3rd generation of BOP theory (BOP 3.0) was developed by taking a step future beyond BOP 1.0 and BOP 2.0. The theory of BOP 3.0 considers the poor as producers entrepreneurs in the literal sense, where these are the ones who are active in seeking partnerships, for example with its stakeholders to support their decisions and actions(Pedrozo, 2015). It can be deemed as sustainable development through innovation and entrepreneurship (Hart, 2017). Mason(2017) believes the emerging BOP 3.0 approach is "now seeking a greater conceptual shift, away from singular solutions of poverty alleviation to understanding how wider innovation ecosystems and engagement through cross sector partnership networks can be developed, to enable a stronger focus on achieving greater levels of well-being in BoP markets". The theory of BOP3.0 is aimed at integrating environmental sustainability concerns along with a triple-bottom-line perspective into BoP initiatives (London 2016).

From BOP theory 1.0 to 3.0, the concept is bound by the environment at BOP and cognitive characteristics of low-income groups (Darwish, 2018), as discussed below:

- $\quad$ For the bottom of pyramid region, scholars believe that there are differences between BOP region and TOP region in capital market, labor market, infrastructure, contract and enforcement' property rights (Webb, 2010). At BOP, systematic arrangement and infrastructure have demonstrated many drawbacks in various aspects (Simons, 2010). Because of asymmetric information and lack of law to regulate the environment, the problem of incomplete market and unprecise information exists. There exsit a lot of SMEs who are not practicing CSR despite the fact that they are claiming the same (Asad, M et al, 2018). This means the market system cannot work effectively (Mendoza, 2008). Meanwhile, adequate infrastructure and service system deficiencies occur at the macro level of ecosystems and society (Fisk, 2016).

- For the people who are at the bottom of the pyramid, they usually lack resources (Mason et al., 2013; Singh et al., 2015) and suffer from uncertainty in decision-making (Dinica and Motteau, 2012), lack of education (Venugopal and Viswanathan, 2017). They are different from affluent people in thinking styles, cognitive limitations, emotional factors, social relationships (Viswanathan and Sreekumar, 2019; Venugopal and Viswanathan, 2017; Choudhury et al., 2019). Although they are resource lean, they are network-rich, which makes them distinctly different from the middle or upper-income literate households (Viswanathan and Sreekumar, 2019). Thus this is the reason why low-income groups are strongly dependent on local social norms and customs for production, living and trading (Mair\&Ventresca, 2012).

Based on above assumptions, BOP theory unceasingly consummates. Authors of the paper believe relationship across three generations of BOP theory is complementary rather than substitute.

Tremendous institutional barriers hindering to start up entrepreneurship can be found at the BOP of an entrepreneurship system. This is because entrepreneurship requires formal institutional arrangements, such as unimpeded information channels, clear definition of property rights, detailed legal provisions and effective implementation. There is institutional void at BOP which makes it difficult for poor people (Mair\&Ventrescai, 2012). De Soto (2000) argued that entrepreneurs coming 
from BOP could not fully capitalise their assets and use their capabilities due to the lack of effective property rights. It is also difficult for them to get basic financial services such as loans and guarantees. The lack of a systematic supporting mechanism makes BOP entrepreneurs rely heavily on social relations to obtain resources. As a result, business activities in the BOP market are controlled by relations and social networks rather than legal contracts (Mair\&Ventresca, 2012).

Poverty reduction requires a shift from the traditional "top-down" to "bottom-up" approach (Abrar-ul-Haq, M., Asad, M, et al, 2020). To help poor people escape the grinding poverty, it is essential to overcome institutional barriers, create opportunities for BOP entrepreneurs and promote their endogenous capacity development (Bhagwati \& Panagariya, 2013). It is not an easy job; it requires strong liaison of enterprises and to build a cross-sector entrepreneurship ecosystem. Within the ecosystem, BOP entrepreneurs are able to access resources (such as finance and technology) to create value, develop capacity and increase income, and eventually achieve the effect of anti-poverty (Rivera Santos et al, 2010; Ramachandran et al ,2012).

\section{Theoretical Framework}

Based on literature review of entrepreneurial ecosystem and BOP theory above, a framework of inclusive entrepreneurial ecosystem is proposed by the authors, as shown in Figure 2.3.

Keeping BOP strategy and inclusive entrepreneurship as the core, sustainable entrepreneurship ecosystem is formed by successful interaction and co-creation among socioeconomic subjects indicated in this diagram. It enables all involved parties to obtain benefits and create values in the entrepreneurial ecosystem. Socioeconomic subjects cooperate with each other and become the conditions for each other's survival and development through complementary advantages, so as to realise shared values and inclusiveness. This framework is validated and refined with clear details based on the incentives, development and multiple actors interaction of taobao ecosystem in the following sessions.

\section{Research Design and Methodology}

This research adopts Case Study methodology for several reasons. Firstly, case study methodology fits the explorative nature of this research to understand "what" and "how" a phenomenon happened (Yin, 2017). Secondly, case study research design can specify gaps or holes in existing theory with the ultimate goal of advancing theoretical explanations (Ridder, 2016). And third, it can provide researchers with contextual richness (Davison \& Martinsons, 2016; Spigel, 2017).

As discussed in earlier sessions, the field of inclusive entrepreneurial ecosystem is under-researched (Autio et al, 2015). In-depth research based on a well-selected case study would enable the researchers to gain a nuanced understanding of different roles and how they interact with each other in an successful inclusive entrepreneurial ecosystem, so that enabler factors could be identified as practical contribution to the research field. Field investigation on 5 Taobao villages are conducted via semi-structured interviews with 62 participants, along with consultation on a large number of periodicals, books, news reports and the official documents produced by Ali Research Institute. The overall roadmap of this research is indicated in Figure 3.1 below.

\section{Rationale for Case Selection: Taobao Village}

There are several criteria for the case selected for this researcher according to the research aim (i.e. to investigate inclusive entrepreneurship ecosystem through the lens of BOP theory) : 1) The selected 
case should be a successful entrepreneurial ecosystem with effective inclusion of the people at bottom of pyramid 2) The selected case should be a rapidly developing entrepreneurial ecosystem; 3) The selected case should be a representative inclusive entrepreneurial ecosystem. Originated from Qing Yan Liu village in Zhejiang Province of East China, three Taobao villages appeared for the first time in 2008. It has attracted great attention from academia because of its inclusion of BOP groups. Different from Silicon Valley in US, it demonstrates significant inclusive entrepreneurship in the ecosystem; A large number of villagers provoked e-commerce businesses through the platform and continuously developed to be the economic main body of the village in various industrial sectors. According to Ali Research Institute (2019), more than 800 Taobao villages are distributed in poverty-stricken counties in 2019. From August 2018 to August 2019, the total annual sales of Taobao online stores in China exceeded 700 billion Chinese Yuan (roughly equals to 77 billion Pound Sterling), accounting for nearly $50 \%$ of the country's rural online retail sales and bringing more than 6.83 million entrepreneurial jobs. (Ali Research Institute, 2019) As a result, Taobao village is the ideal case to this research.

\section{Data Collection Method}

Developing local resources and capabilities to make the entrepreneurial ecosystem work takes time (Clarysse et al.2005). Given that both ecosystem and entrepreneurial activities are dynamic, there is a need to understand how evolution takes place. From vertical time dimension, Taobao ecosystem is based on the unique geographical settlement and acquaintance society in rural China; BOP entrepreneurs developed their entrepreneurial path in the pattern of point -line -face over time. Therefore, data collection process crosses over a time period.

Collecting data from multiple data sources and across different time periods can help avoid researcher's bios via triangulation (Yin, 2017). Supported by findings from literature on Taobao ecosystem regarding its development process, enable factors, entrepreneurial activities of BOP groups, the researchers selected five Taobao villages for field investigation, as shown in Table 3.1.

The primary data was collected through semi-structured interviews with Taobao village's socioeconomic actors. 62 participants from these 5 Taobao villages were selected using theoretical sampling (The Information of interviewees as shown in Table A1 in Appendix). This data process lasted for three months from March 2019 to June 2019, with 3 rounds of interviews with each Taobao village. The interview protocol was originally developed based on theoretical framework (refer to Figure 2.3 in section of "Literature Review"). The $1^{\text {st }}$ round aims to conduct preliminary understanding of basic situation of each Taobao village (as shown in Table A2 in Appendix). According to observations in the $1^{\text {st }}$ round, the researchers revised the questions in $2^{\text {nd }}$ round, which aims to investigate development progress of each Taobao village (as shown in Table A3 in Appendix). The final round of interview focused on interaction across multiple actors within each village. As a result, different sets of questions were designed for each category of actors along with general ones (as shown in Table A4 in Appendix).

Each interview lasted about 1.5 hours, with recording permission granted by participants. In order to ensure reliability and validity of research conclusion, agile approach is adopted in this practical investigation process and the interview protocol was revised continuously according to investigation of Taobao literature and observation from conducted interviews. In addition, interview records were reviewed by the researchers after interviews and uncertainty was clarified by participants via WeChat group at later stage of the practical research. 
This research uses cross-case clustering method to develop horizontal analysis of the samples, including their common features and differences of the upgrade activities between samples. Each selected Taobao village is analysed as a holistic system, and main characteristics of this village are deducted and discussed (in Findings). It would enable the researcher to understand all specific cases in a comprehensive way and identify unique mode of each case. Comparison study was then undertaken on the basis of single case analysis to explore difference, so that new facts are to be discovered. Practically speaking, three steps are involved in the research for data classification and analysis: 1) create a coding scheme to understand collected data (See Figure A1 in Appendix); 2) categories data and identify relationship between categories; 3 ) form theory from the observed patterns.

\section{Findings}

In 2008, three Taobao villages appeared for the first time, which attracted great attention of academia. A large number of villagers at BOP started up business through Taobao eCommerce platform. These businesses were continuously developed to certain size in various industrial sectors which not just limited to agricultural industry, and gradually become the economic main body of the village. Such villages are often described as a canonical example of Taobao ecosystem (Ali research institute, 2019). As shown in Figure 4.1 below, the number of Taobao villages continues to grow. According to Ali research Institute (2019), more than 800 Taobao villages are distributed in poverty-stricken districts in China in 2019. Different from high-tech entrepreneurial ecosystems (such as Silicon Valley and Zhongguancun), Taobao ecosystem enables people at BOP to achieve entrepreneurship.

Taobao ecosystem is also a cross-sector entrepreneurial ecosystem since it integrates the resources and capabilities of every possible party e.g. BOP entrepreneurs, government agencies, financial institutions, logistics enterprises, etc. In order to solve the institutional obstacles faced by BOP group as discuss in Literature review, each actor in the system is making use of its core competence to exert the greatest positive influence on the system development. On the basis of inclusion and cooperation with others, each actor not only just create value for themselves, but also enhance integration of technical, human and material resources. This inclusive entrepreneurial system provides BOP entrepreneurs with comprehensive supporting mechanism including both facilities (e.g. working environment and logistics) and services (e.g. government policy and environmental culture).

However, no thorough understanding on how Taobao ecosystem works in current literature and what are direct incentives of its emergence. In order to find answers to these questions, empirical research on 5 selected Taobao villages examines the construction process of Taobao ecosystem and interaction among its multiple actors. Its findings are presented below.

\section{Finding 1 - ICT empowers to BOP Entrepreneurs}

BOP 3.0 theory advocates that low-income groups should integrate into the mainstream economy and share the benefits brought by economic growth through equal opportunities for entrepreneurship (Ruimei, P\&Xiaoqiang, X, 2019). But in practice, outmoded logistics industry, broadband and transportation are the common problems confronted by BOP entrepreneurs, which led to the digital divide between urban and rural areas. In recent years, infrastructure construction in rural areas has been significantly improved by investment from Chinese government. The infrastructure of highway, power, water, cable television network, and especially the Internet has covered the vast rural areas at an 
unprecedented speed, laying a solid hardware foundation for people at BOP. As ICT effectively links consumers with product producers, service providers and traders, it can promote the emergence of digital entrepreneurs (Srinivasan \& Venkatraman, 2018). In the context of the Internet, digital technology is seen as an effective way to promote development and alleviate poverty. However, in current literature, there is a tremendous gap in understanding of entrepreneurship in the digital age (Sussan, F., \& Acs, Z. J, 2017). Taobao ecosystem appears exactly in the digital era. The first finding from empirical study of this research is that ICT empowerment to BOP entrepreneurs is the most direct inducement for the formation of its ecosystem, which is discussed in details below.

Access empowerment: ICT connects the region at BOP to modern market

ICT enables disintermediation of distribution channels, so that BOP entrepreneurs can connect with modern market directly via the Internet. Dissimilar from high-tech entrepreneurial ecosystems which achieve sustainability through the research and development of new technology products, Taobao ecosystem integrates resources in the BOP area via ICP for inclusive and sustainable development. Our interview results suggest for BOP entrepreneurs, connection between BOP region and modern market has incomparable great value because it enables them to access to appropriate information and opportunities (see Table 4.1 below).

Resource empowerment: ICT eliminates people's over-dependence on natural resources

Knowledge, formal authority, social relations and discursive resources are necessary for entrepreneurial activities to certain extent (Wright et al, 2013). However, research suggests that comparing with elite entrepreneurs, marginalised entrepreneurs usually face the predicament of lack of resources (Waldron et al, 2015). This viewpoint can be further supported by our interviews with BOP entrepreneurs in Taobao villages:

"Young people in the village usually go out to work before they graduate from junior high school, so they have little knowledge. "--BOP entrepreneur of WanTou Village

"When I started my business, I didn't have enough money to start it. Then I had to borrow money from my brothers and sisters to start my business."--BOP entrepreneur of BaiNiu village

"When I went out to work, I met many villagers. But because the living environment is the same, the information we get is almost the same."--BOP entrepreneur of XiaYing Village

On the contrary, entrepreneurs in high-tech entrepreneurial ecosystem such as Silicon Valley generally have high educational background, professional knowledge, social capital and other advantages (Fairlie,2013). In general, there are rich natural resources in BOP region, especially green ecological resources (DU, 2018). Thus, BOP entrepreneurs are overly dependent on natural resources, which unfortunately is not enough to support sustainable entrepreneurial activities. ICT helps the BOP entrepreneurs to obtain financial, human and knowledge resources, as shown in Table 4.2 below.

\section{Psychology empowerment: ICT encourages people to participate in entrepreneurial activities}

- $\quad$ More Choices of Lifestyle

When the people at BOP is limited by the lack of resources and capacity, they have no choice for their life. Capacity building enables members to find solutions to the obstacles they face in life (Abrar-ul-Haq, M., Asad, M et al, 2020). Because of inclusive entrepreneurship empowered by ICT as 
discussed above, people has access to information, opportunities and resources, and as a result, enhances control over life. The experience of Zhao Liqin, a villager in Dongfeng Village, is a typical example.

\begin{abstract}
"Almost all youngsters in Dongfeng Village used to go out to work. Since a young open first Taobao store in 2010, after then 90 percent of the village's migrant workers have returned to home. My husband and I are no exception. When I return to my village, I works as a customer service for a Taobao store. Compared with the previous job which is to sell snacks from dawn to dusk in the city, this job is easier and paid more. In the meanwhile, our living accommodation is continue improved." -- Zhao Liqin, BOP entrepreneur in DongFeng Village
\end{abstract}

- $\quad$ More Impacts of BOP products

BOP entrepreneurs possess a wealth of tacit knowledge, such as the science or art of cultivating crops, traditional crafts and secret folk recipe etc. For example, people live in WanTou village own a traditional skill which can named woven straw. Inclusive entrepreneurship enabled by ICT helps products made by the tacit knowledge gain more influence in modern market. By the inculcation of cottage industry not only self-employment is created but cottage industry also results in employment generation and thus, creates a multiplier effect in the overall economic growth (Haider, S. H., Asad, M et al , 2015). In an interview, a government officer of WanTou village said as follows:

"In our village, people are so ingenious that they can make the most remarkable handicrafts such as fan or straw sandals from the most ordinary pampas grass. This traditional skill which name is woven straw has been handed down from age to age for more than 800 years. But until the booming of the online shopping market, China's woven straw items from our village are popular for their elegant designs and practically in all over the world." --A government officer of WanTou village

- $\quad$ More Inclusion of Vulnerable Members

In Taobao village, vulnerable members of our society such as women, disabled people and the elderly can also become entrepreneurs, consumers or producers with the help of ICT. Lu Zhenhong, the business leader of Beishan village, told us the story of his younger brother during an interview:

"My little brother named LV Lin has suffered from muscular dystrophy since childhood and is incapable of doing physical work. With my help, he was attempting to teach herself how to use a computer and starting a taobao shop to sell outdoor goods. Through entrepreneurship, my little brother not only to become self-sufficient, but also changed his mental outlook and makes life worthwhile."--Lu Zhenhong, business leader of BeiShan village

\title{
Finding 2 - Development Process of Taobao Ecosystem
}

Besides ICT empowerment to BOP entrepreneurs in terms of access, resources and psychology as discussed above,formation process of Taobao ecosystem is also essential to be analysed in order to find its unique advantages. Figure 4.2 below summerises its "point-line-plane" development process of entrepreneurial activities in Taobao villages based on interviews.

\section{Stage 1: Entrepreneurial leaders find entrepreneurial opportunities (Point)}

As shown in Figure 4.2, the development of Taobao ecosystem is from bottom to top: the entrepreneurial leaders at BOP started their own businesses at the initial stage and grew 
spontaneously (i.e. 'Point' stage). The use of the Internet has expanded the social network of BOP entrepreneurs, making it easier not only to maintain existing relationship with acquaintance society, but also to establish new connection in the virtual community, and finally brings BOP entrepreneurs more entrepreneurial opportunities. In this case, entrepreneurial leaders have an opportunity to build micro and small enterprises. Entrepreneurial orientation and innovation were very important for improvement in performance of MSEs (Asad, M., Shabbir et al, 2018). The specific content of the interview is as follows:

"I browsed the Internet community and found that people can trade through Taobao platform. So this led me to launch a business idea of selling iron handicraft and put it into practice." --Li Jiangbin, business leader of ZaoMei Village

"My undergraduate major is e-commerce, so I am familiar with the Internet. I find that the Internet may be able to make Turquoise from our village sales better. So I tried to open a Taobao store in 2009."

--Jiang Kai Ming, business leader of XiaYing Village

\section{Stage 2: Entrepreneurial followers realise entrepreneurial fission (Line)}

With the start-up followers starting to copy the business model at the second stage, the wealth effect of Taobao village quickly spread to the surrounding villages and towns (i.e. 'Line' stage). As Chinese countryside is an acquaintance society, people trust each other in a relatively closed space and it has obvious self-organisation (Fei, 1992). Therefore, there are few barriers for the diffusion of entrepreneurial information and tacit knowledge of grassroots entrepreneurs in rural areas. Based on the strong tie with entrepreneurial followers, business leaders will share their tacit knowledge to entrepreneurial followers without reservation. Therefore, the first batch of entrepreneurial followers are often the closest relatives and friends of business leaders.

"After I started my business, some relatives and friends came to me to ask about e-commerce business. We are all acquaintances, so I must teach them. There are more and more people from the village behind to study. "--Li Jiangbin, Business leader of Zao Mei Village

"At that time, we saw Li Jiangbin (Business leader of ZaoMei Village) drive a BMW around the village every day. We all admired him and wanted to know how he got rich after all. We asked him about the secret of making money, because we are all relatives, so he was very willing to tell us"--BOP Entrepreneur of Zaomei Village

By spreading the entrepreneurial experience and the business model step by step, entrepreneurs make the entrepreneurial activities which have the similar business models appear in the neighboring villages, as shown in figure 4.3 .

\section{Stage 3: Taobao Ecosystem is formed (Plane)}

Finally, with the increase of socioeconomic actors, Taobao ecosystem is formed, which includes office, warehousing and logistics, business services, business incubation and training (i.e. 'Plane' stage). This directly led to the emergence of third-party e-commerce service providers (e.g. logistics companies such as Shunfeng \&Shentong, and financial institutions such as Yixing in Taobao ecosystem. Under the moderating effect of environment, generating and taking actions in response to market intelligence by the participation of a variety of departments in the organization positively correlated with the performance of SMEs (Asad, M., Chethiyar, S. D et al, 2020). So this provides BOP entrepreneurs with 
more opportunities to be more inclusively involved in the system, e.g.:

"I also want to do online sales of iron rattan furniture at the beginning. But then I saw that so many young people were already doing this, and everyone generally reflected that there was a large demand for logistics and transportation, so I started the logistics business."--Logistics practitioners in ZaoMei village.

"Every day, I will publicize to the villagers who come to my supermarket that Taobao can help them to buy goods and collect and distribute parcels. Many elderly villagers, especially those with left behind children, come to me to help them buy daily necessities, snacks, shoes and clothes on Taobao platform."--Liu Bin, who help villagers buy goods from the Internet.

Development of various services, on the other hand, increases the demands of relevant professional knowledge and labours, such as photography, graphic design, packaging and distribution et. As the positive influence of wide existence of service providers, rural residents can now participate in entrepreneurial activities and contribute to inclusive and sustainable development of the entrepreneurial ecosystem as return.

\section{Finding 3 - Co-Creation in Taobao Ecosystem}

As seen from previous discussion, inclusive ecosystem development is the result of interaction between multiple actors. Value creation requires the participation of various economic and social entities through the interaction and exchange of tangible and intangible resources (Adner, 2010; Autio, 2015). This empirical study also discloses how different participants in Taobao ecosystem interact with each other, including SMEs founded by BOP entrepreneurs, government agencies, social organisations, ICT industry, logistics industry and so on. The findings can be summerised in Figure 4.4 below.

In the Taobao ecosystem, interaction and cooperation of multiple participants can gather a large number of heterogeneous resources. As indicated by interview findings and Ali Research (refer to Table $4.3)$, transformation and creation of shared value can be realised via interactive cooperation and resource integration to satisfy business requirements of each participant.

\section{Conclusions and future research}

\section{Revision of Inclusive Entrepreneurial Ecosystem Framework}

Findings from both primary and secondary research indicate that the essence of Taobao ecosystem is the product of embedding technology in local social network. Via the Internet, the digital economy is increasingly manifested as a distributed, collaborative network in the industrial division of labor. By accessing to this network, people in poverty-stricken areas could become valuable "nodes" in the Internet, which can help them maintain a relatively equal relationship with the other "nodes" in developed areas. Small and micro entrepreneurial enterprises founded by the people at BOP are highly fit with other socioeconomic actors in the entrepreneurial ecosystem. By complementing each other's advantages, they gradually become survival and continuous development conditions of each other and finally achieve sustainable development of the entire ecosystem. The revised framework of inclusive entrepreneurial ecosystem is shown in the Figure 5.1 below.

This framework provides some enlightenment for policy and research. as summerised as below:

- The empowerment of ICT to BOP entrepreneurs is incentive in an inclusive entrepreneurial 
ecosystem especially in the digital era. ICTs not only connect the BOP area with the modern market to create open opportunities, but also eliminate the excessive dependence on natural resources at $\mathrm{BOP}$.

- Entrepreneurial development path of BOP entrepreneurs in Taobao ecosystem is a process from point (i.e. single entrepreneurial leader's success) to line (i.e. achievement of entrepreneurial replication and industrial chain extension) to surface (i.e. formation of entrepreneurial ecosystem). Briefly speaking, the process starts with pioneering entrepreneurs' eCommerce engagement and business model innovation. Then followers of entrepreneurship copy the successfully business model. With the entry of various social and economic participants, as well as the competition and division of labor among online enterprises, an entrepreneurial ecosystem is finally formed.

- Inclusiveness is an important enable factor of a sustainable entrepreneurial ecosystem. Co-creation can be realised because of inclusion an engagement of every actor in an entrepreneurial ecosystem. Through the interaction between economic and social actors, their resources can be integrated and multi-value collaborative creation can be achieved. BOP groups can play multiple roles, such as consumer, producer and entrepreneur, in the value chain.

\section{Conclusion and Recommendation for Future Research}

This study proposed a framework for inclusive entrepreneurial ecosystem through the lens of BOP theory, based on findings of both literature review and empirical study of Taobao ecosystem in China. The theoretical contribution of this study lies in two aspects. On the one hand, this study clearly proposed the theoretical framework of inclusive entrepreneurial ecosystem. As a new entrepreneurial paradigm, inclusive entrepreneurship is a new form of entrepreneurship to deal with complex social problems. However, there are few studies on inclusive entrepreneurial ecosystem. Based on this, this study proposed an initial framework for inclusive entrepreneurial ecosystem through the lens of BOP theory, based on findings of literature review. According to case study of Taobao Village, this paper further improves the elements of the entrepreneurial ecosystem theoretical framework. Finally, a more perfect theoretical framework of inclusive entrepreneurial ecosystem is proposed. On the other hand, this paper reveals the internal mechanism of the formation and development of the inclusive entrepreneurial ecosystem. As a living case of inclusive entrepreneurship ecosystem, Taobao village is a worthy of study unique phenomenon all worldwide. This paper opens the black box of the entrepreneurial ecosystem of Taobao village by sorting out its causes, development process and interaction between each socioeconomic actor. It provides theoretical understanding on how to successfully form a sustainable entrepreneurial ecosystem by integrating BOP entrepreneurs in value chain. And it is helpful to further improve the relevant theories.

The successful experience of Taobao village can provide contributions and implications for the management in practice. Firstly, socioeconomic actors in an inclusive entrepreneurial ecosystem can identify their functional roles in the entrepreneurial ecosystem by comparing theoretical models. To be specific, entrepreneur leaders can further play an exemplary role, sharing more entrepreneurial tacit knowledge within Taobao Village, so as to help more people who are at the bottom of the pyramid become entrepreneurs. The government not only actively build an inclusive social atmosphere through policy-making, but also provides more education, training and public services for entrepreneurs who come from the bottom of the pyramid. The ICT industry, finance industry, logistics industry and other 
related industries should gradually improve relevant supporting services. Second, this can provide theoretical guidance for other countries and regions to build inclusive entrepreneurship ecosystems, and help them to check and fill the gaps and build inclusive entrepreneurship ecosystems based on their local characteristics. Some "Taobao villages" are developed on the basis of their unique resources or traditional industries and they cannot be copied easily. However, as long as each region finds its own unique advantages and relies on the e-commerce platform, it will have the opportunity to develop its unique inclusive entrepreneurship ecosystem. So this paper provides reference for other countries and regions to learn from the successful experience of the existing inclusive entrepreneurship ecosystem. Not only help people achieve the local replication of the inclusive entrepreneurial ecosystem (such as the phenomenon of "Taobao village" growing into "Taobao town"), but also achieve cross-regional and even cross-border replication. Finally, this study provides theoretical guidance for solving the problem of poverty at the bottom of the pyramid, transforming the poor from the objects of help to successful entrepreneurs, and thus realizing regional sustainable development. In the inclusive entrepreneurship ecosystem, people at the bottom of the pyramid have their inherent motivation for poverty alleviated through becoming an entrepreneur, which is of unique reference significance for solving the current global poverty problem.

However, the complexity of entrepreneurial ecosystem facing BOP poses a major challenge to its actual operation. Therefore, it is necessary to study the driving factors of inclusive entrepreneurial ecosystems. In particular, ecosystem is a purposeful collaborative network of dynamic interactive systems, which has a set of changing dependencies in a given context. Research is still limited on socioeconomic actors' interaction with each other in each stage to promote the evolution of entrepreneurial ecosystem. The extent to which they are intentionally designed or organically produced is still unclear, which is recommended for future study in this field.

\section{References}

Abrar-ul-Haq, M., Asad, M., Natarajan, V., Sankar, J. P., \& Asif, M. U. (2020). 2020 Microfinance and empowerment: A case study on benificiaries of a community development program. Hamdard Islamicus, 43(S1), 378-388.

Acs, Z. J., Estrin, S., Mickiewicz, T., \& Szerb, L. (2017a). Institutions, entrepreneurship and growth: the role of national entrepreneurial ecosystems. Available at SSRN 2912453.

Acs, Z. J., Stam, E., Audretsch, D. B., \& O’Connor, A. (2017b). The lineages of the entrepreneurial ecosystem approach. Small Business Economics, 49(1), 1-10.

Adams, S. B. (2020). From orchards to chips: Silicon Valley's evolving entrepreneurial ecosystem. Entrepreneurship \& Regional Development, 1-21.

Adner, R., \& Kapoor, R. (2010). Value creation in innovation ecosystems: How the structure of technological interdependence affects firm performance in new technology generations. Strategic management journal, 31(3), 306-333.

Ali research institute.(2019). Ten years of taobao village: digital economy promotes rural revitalization--China taobao village research report (2009 2019) [ONLINE] Available at: https://www.useit.com.cn/thread-24636-1-1.html.[Accessed 5 September 2019]. 
Asad, M., Chethiyar, S. D., \& Ali, A. (2020). Total quality management, entrepreneurial orientation, and market orientation: Moderating effect of environment on performance of SMEs. Paradigms, 14(1), 102-108. doi:10.24312/193014016

Asad, M., Haider, S. H., \& Fatima, M. (2018). Corporate social responsibility, business ethics, and labor laws: A qualitative analysis on SMEs in Sialkot. Journal of Legal, Ethical and Regulatory Issues, 21(3), $1-7$.

Asad, M., Shabbir, M. S., Salman, R., Haider, S. H., \& Ahmad, I. (2018). Do entrepreneurial orientation and size of enterprise influence the performance of micro and small enterprises? A study on mediating role of innovation. Management Science Letters, 8(10), 1015-1026. doi:10.5267/j.msl.2018.7.008

Asad, M., Sharif, M. N., \& Alekam, J. M. (2016). Moderating role of entrepreneurial networking on the relationship between access to finance and performance of micro and small enterprises. Paradigms A Research Journal of Commerce, Economics, and Social Sciences, 10(1), 1-13. doi: 10.24312/paradigms100101

Autio, E., \& Levie, J. (2015). Management of entrepreneurial ecosystems. London: Imperial College Business School (mimeo).

Ben Letaifa, S., \& Reynoso, J. (2015). Toward a service ecosystem perspective at the base of the pyramid. Journal of Service Management, 26(5), 684-705.

Bhagwati, J., \& Panagariya, A. (2013). Why growth matters: How economic growth in India reduced poverty and the lessons for other developing countries. Hachette UK.

Cavallo, A. , Ghezzi, A., Colombelli, A. , \& Casali, G. L. . (2018). Agglomeration dynamics of innovative start-ups in italy beyond the industrial district era. International Entrepreneurship \& Management Journal, 1-24.

Cavallo, A., Ghezzi, A., \& Balocco, R. (2019). Entrepreneurial ecosystem research: present debates and future directions. International Entrepreneurship and Management Journal, 15(4), 1291-1321.

Chandrasekhar, C. P. (2017). Private Profit and the Digital Dividend. Development and Change, 48(5), 1196-1209.

Chao-En, W. , Qing, L. , \& Business, S. O. . (2015). Social capital and venture finance selection of migrant workers. Journal of Northwest A\&F University(Social Science Edition).

Choudhury, N., Mukherjee, S., \& Datta, B. (2019). Constrained purchase decision-making process at the base of the pyramid. Journal of Consumer Marketing.

Clarysse, B., Wright, M., Lockett, A., Van de Velde, E., \& Vohora, A. (2005). Spinning out new ventures: a typology of incubation strategies from European research institutions. Journal of Business venturing, 20(2), $183-216$.

Cohen, B. (2006). Sustainable valley entrepreneurial ecosystems. Business Strategy and the Environment, 15(1), $1-14$.

Colombelli, A. , Paolucci, E. , \& Ughetto, E. . (2017). Hierarchical and relational governance and the life cycle of entrepreneurial ecosystems. Small Business Economics, 1-17. 
Darwish, H., \& Van Dyk, L. (2018). Bottom of Pyramid 4.0: modularising and assimilating industrial revolution cognition into a 4-tiered social entrepreneurship upliftment model for previously disconnected communities. Journal of Industrial Integration and Management, 3(02), 1850010.

Davison, R. M., \& Martinsons, M. G. (2016). Context is king! Considering particularism in research design and reporting. Journal of Information Technology, 31(3), 241-249.

De Soto, H. (2000). The mystery of capital: Why capitalism triumphs in the West and fails everywhere else. Civitas Books.

Dembek, K., Sivasubramaniam, N., \& Chmielewski, D. A. (2020). A systematic review of the bottom/base of the pyramid literature: Cumulative evidence and future directions. Journal of Business Ethics, 165(3), 365-382.

Dinica, I., \& Motteau, M. (2012). The market of the bottom of the pyramid: Impact on the marketing-mix of companies. Masterâ€ ${ }^{\mathrm{TM}} \mathrm{s}$ Thesis. Umea School of Business, Umea Univeritet. Dubey, J. \& Patel, RP (2004). Small wonders of the Indian market. Online. Accessed January, 22(2012), 430-438.

Drexler, M., Eltogby, M., Foster, G., Shimizu, C., Ciesinski, S., Davila, A., \& McLenithan, M. (2014). Entrepreneurial ecosystems around the globe and early-stage company growth dynamics. In Geneva: World Economic Forum.

Drofiak, A., \& Garnsey, E. (2019). The Cambridge High Tech Cluster: resilience and response to cyclical trends.

Du, W., Pan, S. L., Zhou, N., \& Ouyang, T. (2018). From a marketplace of electronics to a digital entrepreneurial ecosystem (DEE): The emergence of a meta-organization in Zhongguancun, China. Information Systems Journal, 28(6), 1158-1175.

Fairlie, R. W., \& Chatterji, A. K. (2013). High-technology entrepreneurship in Silicon Valley. Journal of Economics \& Management Strategy, 22(2), 365-389.

Fei, H. T., Fei, X., Hamilton, G. G., \& Zheng, W. (1992). From the soil: The foundations of Chinese society. Univ of California Press.

Feld, B. (2012). Startup communities: Building an entrepreneurial ecosystem in your city. John Wiley \& Sons.

Fisk, R. P. P., Anderson, L., Bowen, D. E., Gruber, T., Ostrom, A., Patrício, L., \& Sebastiani, R. (2016). Billions of impoverished people deserve to be better served. Journal of Service Management, 27(1), 43-55.

Florida, R. , Adler, P. , \& Mellander, C. . (2017). The city as innovation machine. Regional Studies: The Journal of the Regional Studies Association, 51(1), 86-96 .

Foster, G., Shimizu, C., Ciesinski, S., Davila, A., Hassan, S., Jia, N., \& Morris, R. (2013). Entrepreneurial ecosystems around the globe and company growth dynamics. In World Economic Forum (Vol. 11, pp. 1-36).

Fritsch, M. (2013). New business formation and regional development: A survey and assessment of the evidence. Foundations and Trends ${ }^{\circledR}$ in Entrepreneurship, 9(3), 249-364.

Gao Wei. (2015). Research on the Problem of New Generation Migrant Workers Returning to Hometown in China $[D]$ (Doctoral dissertation, Shandong Normal University).

Haider, S. H., Asad, M., \& Almansour, A. Z. (2015). Factors influencing growth of cottage industry in 
Punjab, Pakistan: Cottage industry owners' perspective. Paradigms: A Research Journal of Commerce, Economics, and Social Sciences, 9(1), 78-87. doi:10.24312/paradigms090105

Hammond, A. L. (2011). BOP venture formation for scale. Next generation business strategies for the base of the pyramid: new approaches for building mutual value. Upper Saddle River, NJ: Pearson Education.

Hart, S. L. (2005). Capitalism at the crossroads: The unlimited business opportunities in solving the world's most difficult problems. Pearson Education.

Hart, S. L. (2017). Prologue: defining the path towards a BoP 3.0. In Base of the Pyramid 3.0 (pp. 1-4). Routledge.

Iansiti, M., \& Levien, R. (2004). The keystone advantage: what the new dynamics of business ecosystems mean for strategy, innovation, and sustainability. Harvard Business Press.

Isenberg, D. (2011). The entrepreneurship ecosystem strategy as a new paradigm for economy policy: principles for cultivating entrepreneurship. Babson Entrepreneurship Ecosystem Project, Babson College, Babson Park: $M A$.

Karnani, A. (2006a). Misfortune at the Bottom of the Pyramid. Greener Management International, (51).

Karnani, A. G. (2006b). Mirage at the Bottom of the Pyramid.

Li, L., Du, K., Zhang, W., \& Mao, J. Y. (2019). Poverty alleviation through government-led e-commerce development in rural China: An activity theory perspective. Information Systems Journal, 29(4), 914-952.

Liangzhi, Y. . (2011). Integrative social theories and their relevance for information inequality research:with special reference to bourdieu. Research on Library \& Information Work of Shanghai Colleges \& Universities.

London, T. (2016). The base of the pyramid promise: Building businesses with impact and scale. Stanford University Press.

Mack, E., \& Mayer, H. (2016). The evolutionary dynamics of entrepreneurial ecosystems. Urban Studies, 53(10), 2118-2133.

Mair, J., Marti, I., \& Ventresca, M. J. (2012). Building inclusive markets in rural Bangladesh: How intermediaries work institutional voids. Academy of Management Journal, 55(4), 819-850.

Manimala, M. J., \& Wasdani, K. P. (Eds.). (2015). Entrepreneurial ecosystem. New York, NY: Springer.

Mason, C., \& Brown, R. (2014). Entrepreneurial ecosystems and growth oriented entrepreneurship. Final Report to OECD, Paris, 30(1), 77-102.

Mason, K., Chakrabarti, R., \& Singh, R. (2013). What are bottom of the pyramid markets and why do they matter?. Marketing Theory, 13(3), 401-404.

Mason, K., Chakrabarti, R., \& Singh, R. (2017). Markets and marketing at the bottom of the pyramid.

Mendoza, R. U., \& Thelen, N. (2008). Innovations to make markets more inclusive for the poor. Development policy review, 26(4), 427-458.

Miller, D. J., \& Acs, Z. J. (2017). The campus as entrepreneurial ecosystem: the University of Chicago. Small Business Economics, 49(1), 75-95.

Moore, J. F. (1993). Predators and prey: a new ecology of competition. Harvard business review, 71(3), 75-86. 
O’Connor, A., Stam, E., Sussan, F., \& Audretsch, D. B. (2018). Entrepreneurial ecosystems: The foundations of place-based renewal. In Entrepreneurial ecosystems (pp. 1-21). Springer, Cham.

Pedrozo, E. (2015). Proposition of BoP 3.0 as an alternative model of business for BoP (base of pyramid) producers: Case study in Amazonia. Review by, 189.

Prahalad, C. K. (2012). Bottom of the Pyramid as a Source of Breakthrough Innovations. Journal of product innovation management, 29(1), 6-12.

Prahalad, C. K., \& Hart, S. L. (2002). The Fortune at the Bottom of the Pyramid in Strategy+ Business, Issue: First Quarter, 2002.

Ramachandran, J., Pant, A., \& Pani, S. K. (2012). Building the BoP Producer Ecosystem: The Evolving Engagement of F abindia with I ndian Handloom Artisans. Journal of Product Innovation Management, 29(1), $33-51$.

Ridder, H. G. (2016). Case study research. Approaches, methods, contribution to theory. Sozialwissenschaftliche Forschungsmethoden. Social Science Research Methods, 12.

Rivera-Santos, M., \& Rufín, C. (2010). Global village vs. small town: Understanding networks at the Base of the Pyramid. International Business Review, 19(2), 126-139.

Ruimei, P. , \& Xiaoqiang, X. . (2019). Empowerment enabled by digital technology and inclusive entrepreneurship:based on taobao villages' case. Technology Economics.

Simons, K. L. . (2010). Shakeouts, innovation, and industrial strategy and policy. Australian Economic Review, 40(1), 106-112.

Singh, R., Bakshi, M., \& Mishra, P. (2015). Corporate social responsibility: Linking bottom of the pyramid to market development?. Journal of Business Ethics, 131(2), 361-373.

Spigel, B. (2017). The relational organization of entrepreneurial ecosystems. Entrepreneurship Theory and Practice, 41(1), 49-72.

Srinivasan, A., \& Venkatraman, N. (2018). Entrepreneurship in digital platforms: A network - centric view. Strategic Entrepreneurship Journal, 12(1), 54-71.

Stam, E. (2014) The Dutch Entrepreneurial Ecosystem. Available at SSRN: http://dx.doi.org/10.2139/ssrn.2473475

Stam, E. (2015). Entrepreneurial ecosystems and regional policy: a sympathetic critique. European Planning Studies, 23(9), 1759-1769.

Stam, F. C., \& Spigel, B. (2016). Entrepreneurial ecosystems. USE Discussion paper series, 16(13).

Sussan, F., \& Acs, Z. J. (2017). The digital entrepreneurial ecosystem. Small Business Economics, 49(1), 55-73.

Tansley, A. G. (1935). The use and abuse of vegetational concepts and terms. Ecology, 16(3), 284-307.

Tsvetkova, A. (2015) Innovation, Entrepreneurship, and Metropolitan Economic Performance: Empirical Test of Recent Theoretical Propositions. Economic Development Quarterly 29(4): 299-316.

Venugopal, S., \& Viswanathan, M. (2017). The subsistence marketplaces approach to poverty: Implications for marketing theory. Marketing Theory, 17(3), 341-356.

Viswanathan, M., \& Sreekumar, A. (2019). Consumers and technology in a changing world: the perspective from subsistence marketplaces. European Journal of Marketing. 
Vogel, P. (2013). The employment outlook for youth: Building entrepreneurial ecosystems as a way forward.

Waldron, T. L., Fisher, G., \& Navis, C. (2015). Institutional entrepreneurs' social mobility in organizational fields. Journal of Business Venturing, 30(1), 131-149.

Walsham, G. (1995). Interpretive case studies in IS research: nature and method. European Journal of information systems, 4(2), 74-81

Webb, J. W., Kistruck, G. M., Ireland, R. D., \& Ketchen Jr, D. J. (2010). The entrepreneurship process in base of the pyramid markets: The case of multinational enterprise/nongovernment organization alliances. Entrepreneurship theory and practice, 34(3), 555-581.

Wright, A. L., \& Zammuto, R. F. (2013). Creating opportunities for institutional entrepreneurship: The Colonel and the Cup in English County Cricket. Journal of Business Venturing, 28(1), 51-68.

Yin, J., \& Du, W. D. (2018). Establishing an Ecosystem for Digital Entrepreneurship: A Case of Zhongguancun. Digital Enablement: The Consumerizational And Transformational Effects Of Digital Technology, 139.

Yin, R. K. (2017). Case study research and applications: Design and methods. Sage publications.

Zabir, S. M. S., Ahmed, A., \& Yasuura, H. (2008, July). Digital divide: The amazing fact at the BoP. In Proceedings of IADIS International Conference on ICT, Society and Human Beings.

\section{Appendix}

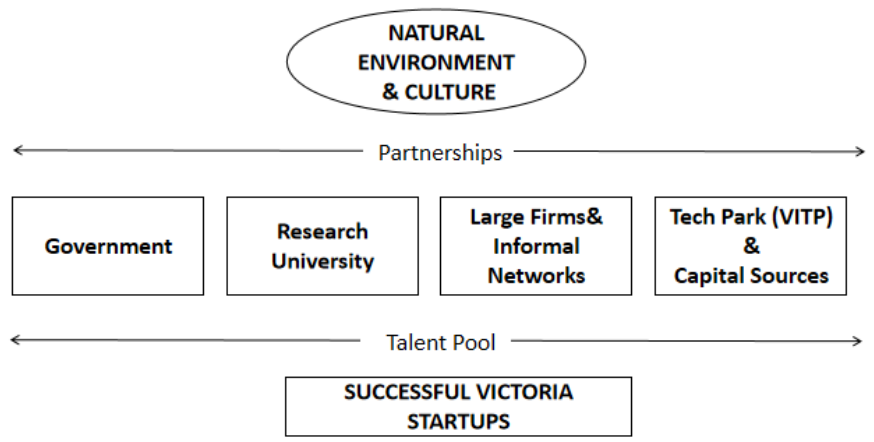

Figure 2.1 Cohen's sustainable entrepreneurship ecosystem model (Source: Cohen,2006). 

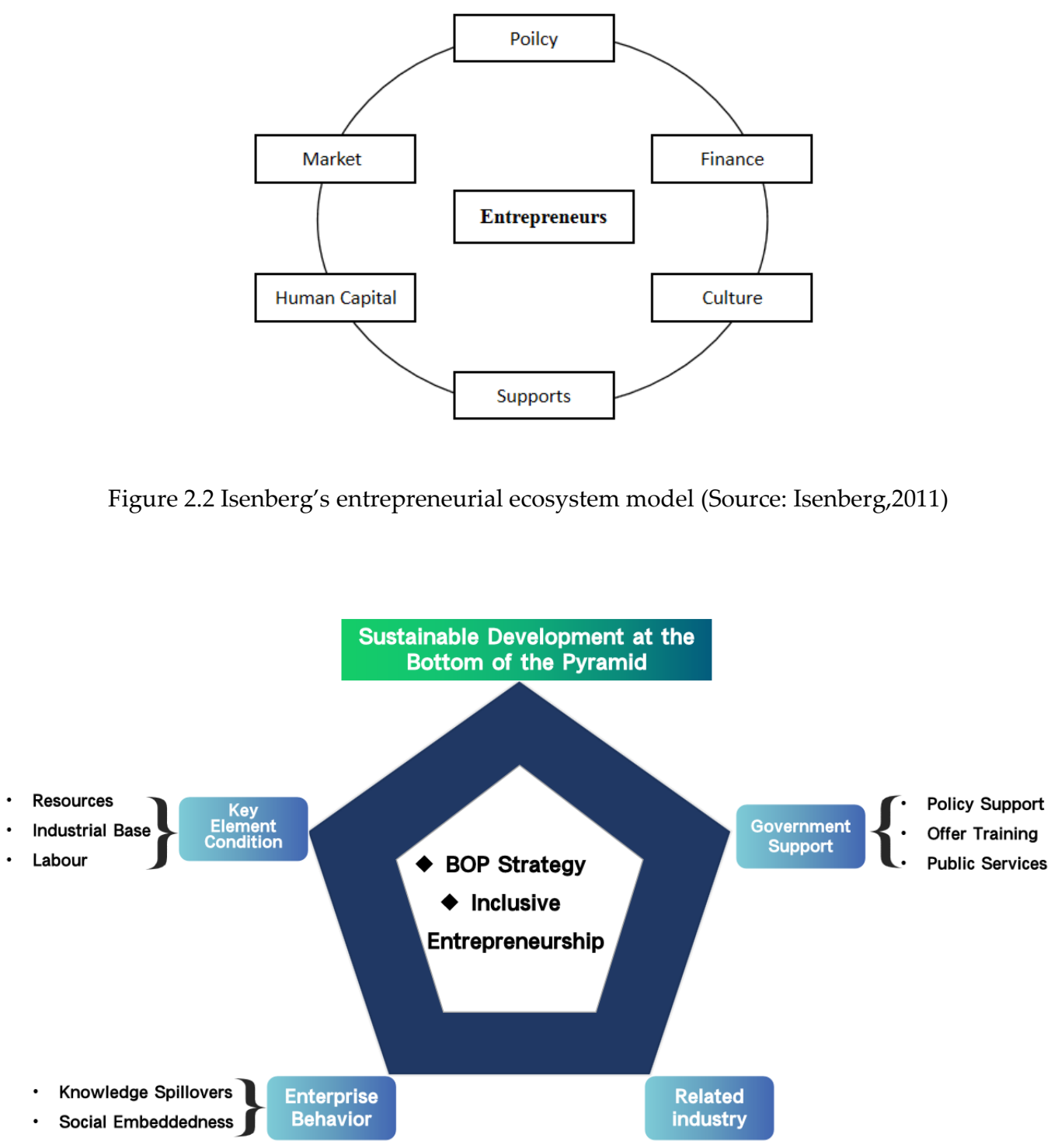

Figure 2.3: The inclusive entrepreneurial ecosystem based on BOP theory (source: the authors) 


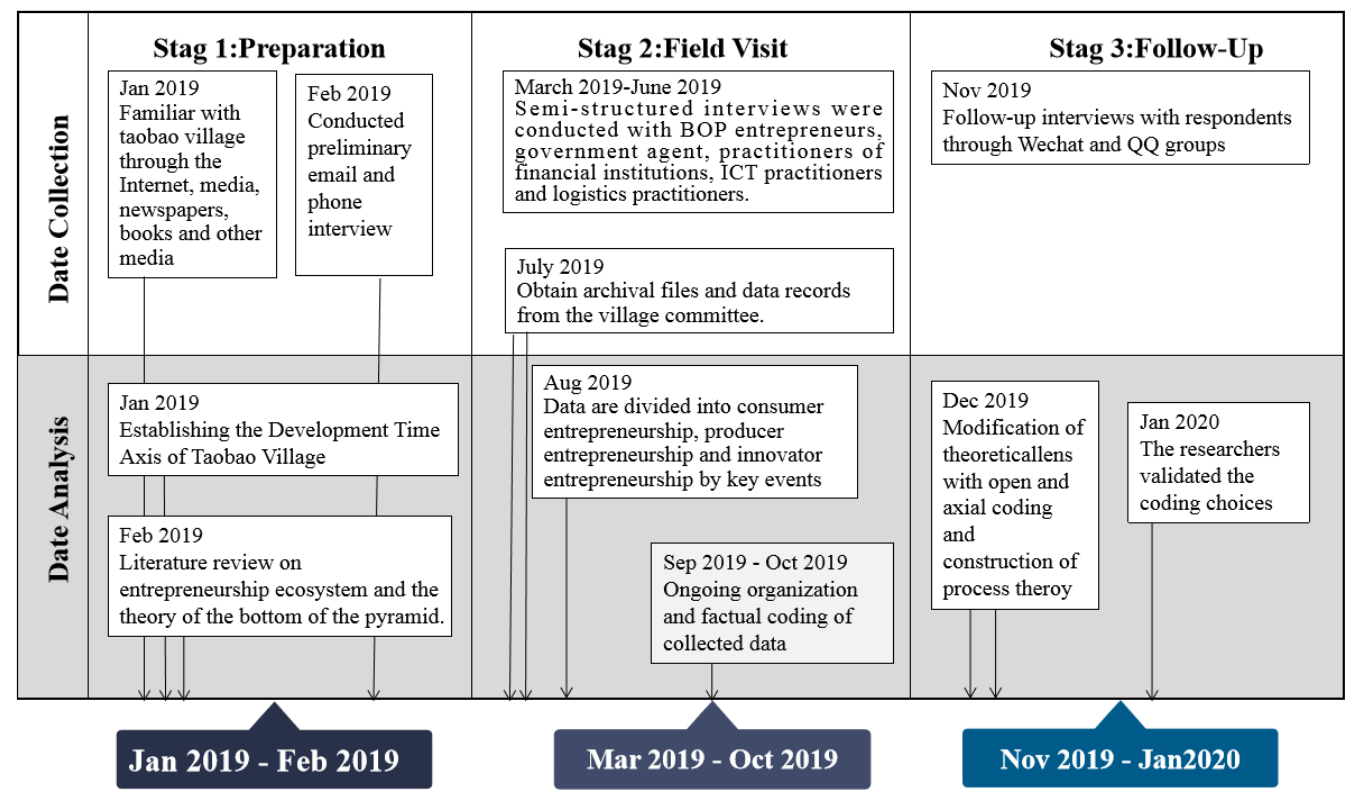

Figure 3.1 Research road map (source: the authors)

\begin{tabular}{lll}
\hline Taobao village & Main Business & Geographical Location \\
\hline BeiShan village & Outdoor product & Jinyun county, Zhejiang province \\
\hline XiaYing village & Turquoise & Shiyan City, HuBei province \\
\hline BaiNiu village & Pecan & Hangzhou City,ZheJiangprovince \\
\hline ZaoMei village & Iron rattan furniture & Quanzhou City, Fujian Province \\
\hline WanTou village & Handicrafts & Qingdao city, shandong province \\
\hline
\end{tabular}

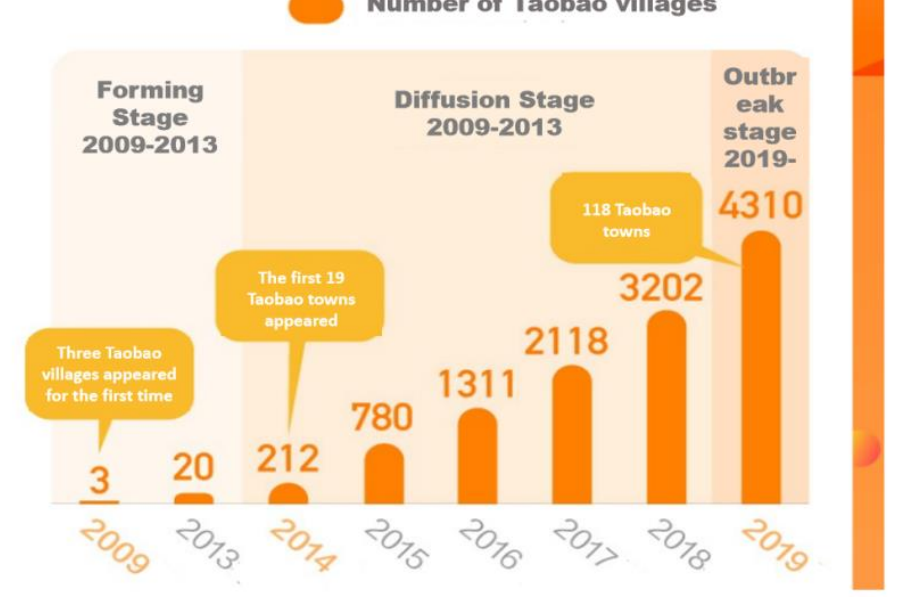




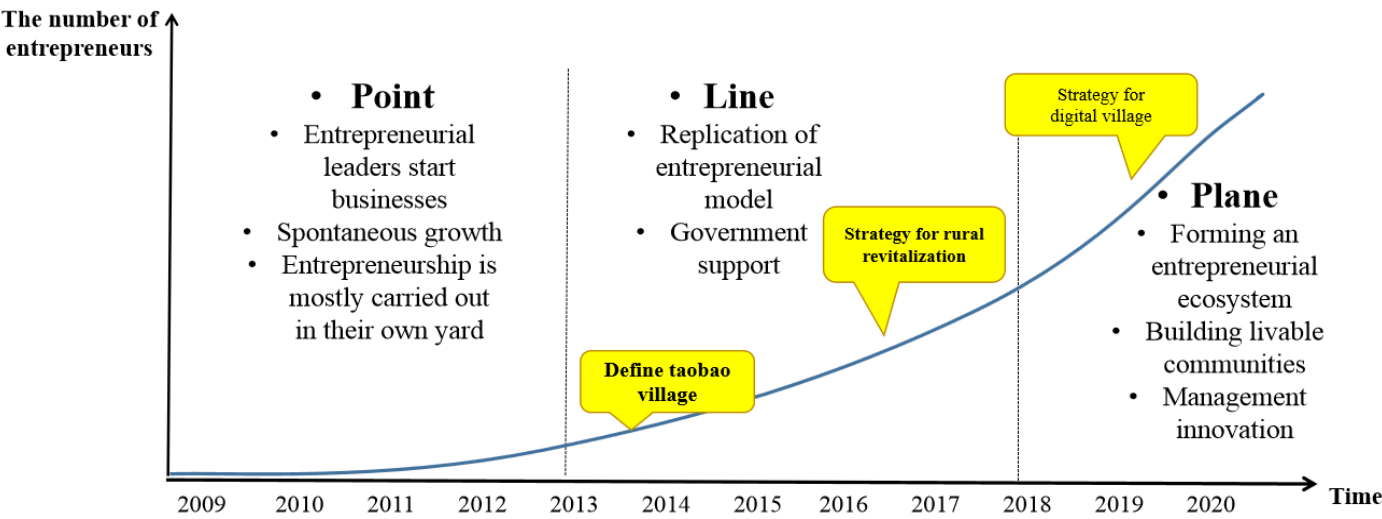

Figure 4.2 The development process of entrepreneurial activities in Taobao villages (source: the

The native villagers and the people from nearby villages authors)

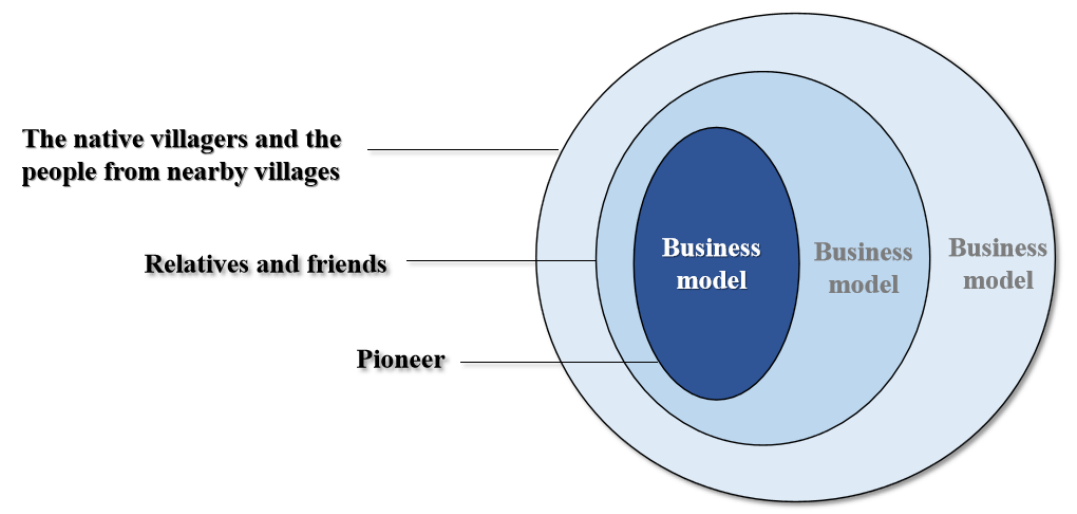

Figure 4.3: Entrepreneurial fission in Taobao ecosystem (source: the author)

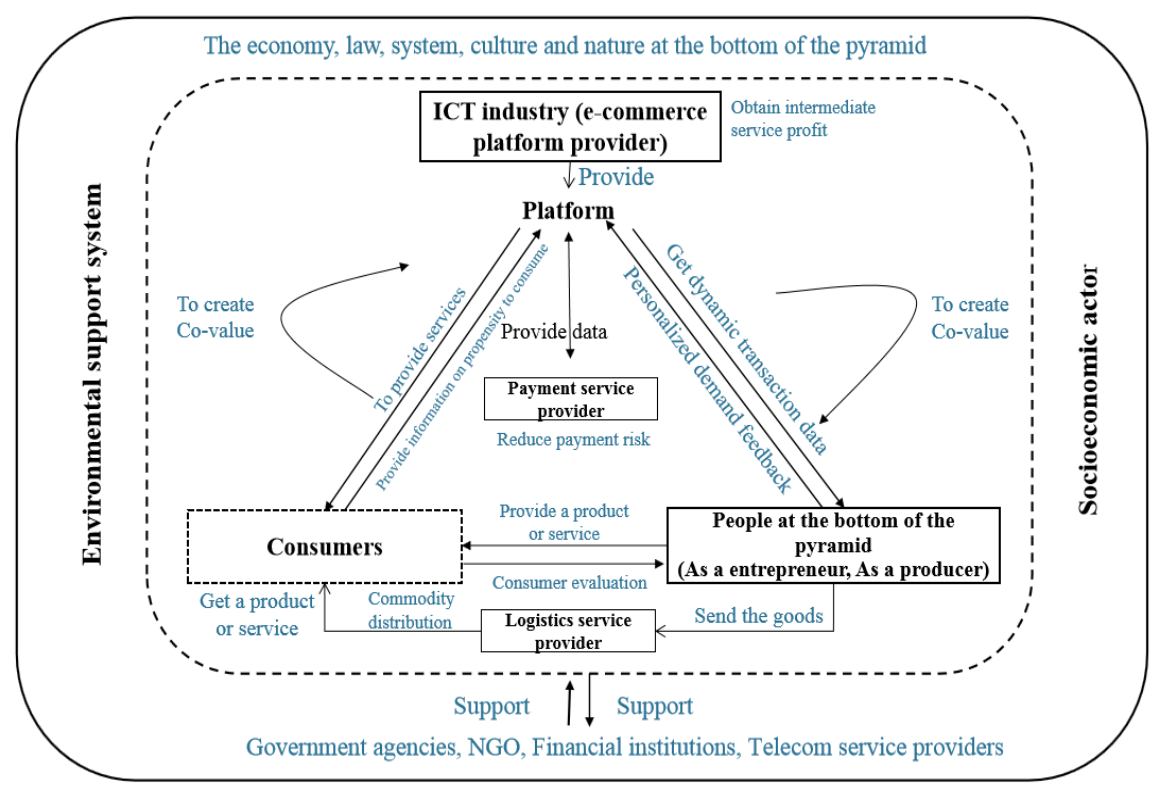




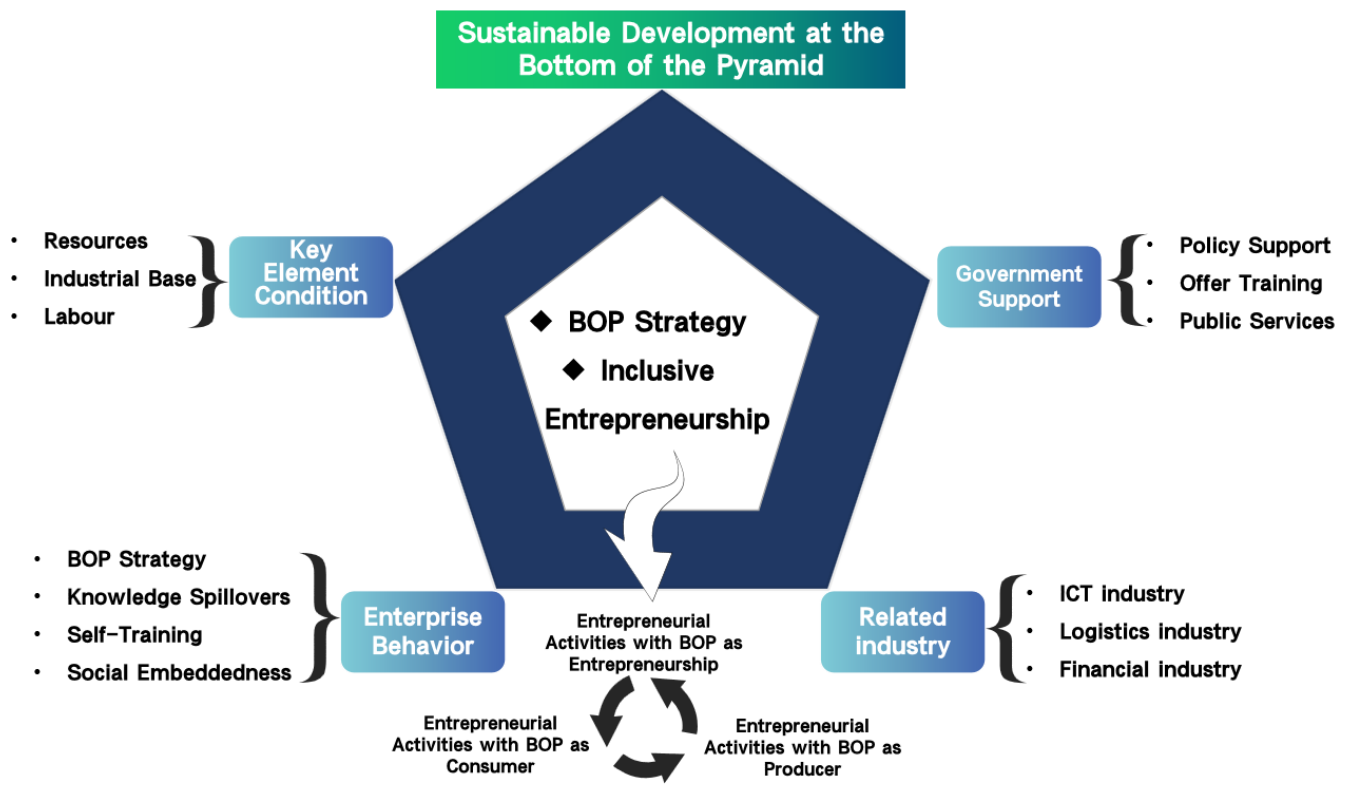


- "Our village has a lot of turquoise. We knew it has a highly ornamental value before, but not many people bought it, so we didn't pay more attention on it. Until an young which named Jiang Kai Ming through Internet find that people who live in southeast Asia believe in Buddhism, and turquoise is regarded as a holy object in those place. There is a huge demand for Turquoise in these countries. Those information promoted Jiang Kai Ming to open the first Taobao store in our village. Since then, our village's turquoise has become a best-selling product and sold

Access

to

Informatio

$\mathrm{n}$ overseas" -- BOP entrepreneur of XiaYing Village

"Based on the sales data of outdoor products provided by Taobao Village platform, we analyzed our advantages and disadvantages compared with competitors and adjusted our business strategy. More importantly, we can analyze consumers' potential consumption preferences according to the information, and then continuously innovate to launch new outdoor products such as envelope-type sleeping bag and blue tent."--BOP entrepreneur of BeiShan Village
Information, as a factor of production, has become more essential with the advent of the digital economy era. Information inequality leads to information isolation. (Liangzhi, Y., 2011). This kind of information isolation not only makes the people at BOP at a disadvantage in the market competition, but also causes their commodities are not recognised by the mainstream market. ICT can help BOP entrepreneurs to obtain the same information as the mainstream market crowd, which is conducive to the inclusive entrepreneurship.
- "Provided that these pecans are sold in the local market of Lin'an, Zhejiang Province, we not only have to reduce our prices because we must face homogeneous competition, but also have a market capacity limited. But the total population of Jiangsu, Zhejiang and Shanghai is about 220 million, nearly 400 times the total population of Lin 'an, which provides a bigger market for our village. Our village sold our goods to a big coastal city on the Internet since 2009. During the ten years of development from 2009 to 2019, our village has achieved an explosive growth in sales volume from 1 million yuan to 350 million yuan. In 2018, the per capita annual income of our village reached 33500 yuan, solving the problem of more than 400 rural people's employment. A package of pecans not only brought more young people back to our hometown to start businesses, but also made the village out of poverty" - Business leader of BaiNiu Village

Access

- Before 2008, a large number of weaving was exported to Opportuni ties through foreign trade channels, but the global financial crisis triggered the adjustment of the international market pattern, the export channel blocked, a large number of foreign trade orders had to seek domestic sales channels. We were in a great hurry at that time, because if we didn't have a chance to sell handicrafts, our income would drop sharply. At that time, e-commerce, as the fastest domestic sales channel, added wings to the development of e-commerce in our village.It gives us the opportunity to sell a large number of products and solve our pressing
According to the world bank research, digital dividend is the growth, employment and service income brought by digital investment

(Chandrasekhar, 2017). Compared with the sales in the local market, the excess revenue generated by the sales of goods through the Internet is the typical digital dividend. ICT helps the BOP entrepreneurs access the opportunity to the digital dividend. 


\begin{tabular}{lllll}
\hline Resources & $\begin{array}{l}\text { What? } \\
\text { recourses }\end{array}$ & Definition of & $\begin{array}{l}\text { How? Examples from } \\
\text { Interviews }\end{array}$ & $\begin{array}{l}\text { Why? The needs of } \\
\text { BOP entrepreneurs }\end{array}$ \\
\hline
\end{tabular}




\begin{tabular}{|c|c|c|c|}
\hline \multirow[t]{3}{*}{$\begin{array}{l}\text { Financial } \\
\text { resources }\end{array}$} & \multirow{3}{*}{$\begin{array}{l}\text { Financial resources refer to } \\
\text { various monetary resources } \\
\text { available to the entrepreneur } \\
\text { in the process of discovering } \\
\text { and implementing } \\
\text { entrepreneurial ideas, which } \\
\text { provide financial support for } \\
\text { enterprise operation. }\end{array}$} & $\begin{array}{l}\text { Government advocates } \\
\text { Internet finance and } \\
\text { provides financial services } \\
\text { for the people at BOP. }\end{array}$ & \multirow{3}{*}{$\begin{array}{l}\text { Most of the BOP } \\
\text { entrepreneurs rely on } \\
\text { their own funds and } \\
\text { have few financing } \\
\text { channels. Only a few } \\
\text { entrepreneurs can } \\
\text { obtain loans with formal } \\
\text { financial institution. } \\
\text { (Chao, 2015). } \\
\text { The access to finance } \\
\text { offered by micro-finance } \\
\text { institutions positively } \\
\text { influence performance } \\
\text { of micro and small } \\
\text { enterprises (Asad, M et } \\
\text { al, 2016) }\end{array}$} \\
\hline & & $\begin{array}{l}\text { eCommerce platform } \\
\text { has launched online } \\
\text { financial services such as }\end{array}$ & \\
\hline & & Alipay. & \\
\hline \multirow[t]{2}{*}{$\begin{array}{l}\text { Human } \\
\text { resources }\end{array}$} & \multirow{2}{*}{$\begin{array}{l}\text { Human resources include } \\
\text { entrepreneurs, supporters, } \\
\text { team members, etc. It covers } \\
\text { the judgment, insight, } \\
\text { creativity, vision and } \\
\text { intelligence of each } \\
\text { individual in the } \\
\text { organization, and even the } \\
\text { entrepreneur's social skills. }\end{array}$} & $\begin{array}{l}\text { Use the Internet to } \\
\text { purchase professional } \\
\text { design, photography, } \\
\text { trademark registration, } \\
\text { legal advice and other } \\
\text { professional services }\end{array}$ & \multirow[t]{2}{*}{$\begin{array}{l}\text { There is a serious brain } \\
\text { drain phenomenon that } \\
\text { people in BOP area } \\
\text { usually lack of } \\
\text { professional skills. (Gao, } \\
2015 \text { ) }\end{array}$} \\
\hline & & $\begin{array}{l}\text { The people at BOP } \\
\text { improve their professional } \\
\text { skills through Internet } \\
\text { training courses }\end{array}$ & \\
\hline \multirow[t]{2}{*}{$\begin{array}{l}\text { Knowledge } \\
\text { resources }\end{array}$} & \multirow[t]{2}{*}{$\begin{array}{l}\text { Knowledge resources include } \\
\text { technology resources, } \\
\text { intelligence resources, } \\
\text { information resources and so } \\
\text { on }\end{array}$} & $\begin{array}{l}\text { Through the Internet } \\
\text { search to open shop } \\
\text { knowledge and skills. } \\
\text { Learn explicit knowledge } \\
\text { of online shop decoration, } \\
\text { product appearance } \\
\text { design, etc }\end{array}$ & \multirow[t]{2}{*}{$\begin{array}{l}\text { People at BOP in } \\
\text { general are poor and } \\
\text { undereducated. (Zabir, } \\
\text { 2008). }\end{array}$} \\
\hline & & $\begin{array}{l}\text { Use social media } \\
\text { platforms, such as } \\
\text { WeChat, to consult the } \\
\text { business leaders about the } \\
\text { tacit knowledge of } \\
\text { product and market } \\
\text { positioning, operation, } \\
\text { channel, customer service } \\
\text { skills, and profit model } \\
\text { etc. }\end{array}$ & \\
\hline $\begin{array}{l}\text { Participants } \\
\text { in Taobao } \\
\text { Ecosystem }\end{array}$ & $\begin{array}{l}\text { Business Requirements } \\
\text { in Co-creation }\end{array}$ & Examples & \\
\hline Government & $\begin{array}{l}\text { To solve the most difficult } \\
\text { poverty alleviation } \\
\text { problems at the lowest } \\
\text { cost. }\end{array}$ & $\begin{array}{l}\text { 2018, our village's e-commer } \\
\text { million yuan, becoming } \\
\text { ge."--Government officer of }\end{array}$ & $\begin{array}{l}\text { ce business income reached } \\
\text { a well-known wealthy } \\
\text { XiaYing Village }\end{array}$ \\
\hline
\end{tabular}




\begin{tabular}{|c|c|c|}
\hline $\begin{array}{l}\text { ICT Industry } \\
\text { (e-commerce } \\
\text { platform } \\
\text { provider) }\end{array}$ & $\begin{array}{l}\text { The platform needs to } \\
\text { attract new customers and } \\
\text { suppliers in the sinking } \\
\text { market. }\end{array}$ & $\begin{array}{l}\text { According to Alibaba's financial report, } 77 \% \text { of Taobao } \\
\text { tmall's new } 100 \text { million active users in } 2019 \text { come from the } \\
\text { third and fourth tier cities and rural areas (Ali Research } \\
\text { Institute, 2019). }\end{array}$ \\
\hline $\begin{array}{l}\text { Logistics \& } \\
\text { Financial } \\
\text { Industry }\end{array}$ & $\begin{array}{l}\text { Enterprises acquire a } \\
\text { large number of potential } \\
\text { customers }\end{array}$ & $\begin{array}{l}\text { "SF express created a three-level logistics system. This logistics } \\
\text { system enables fresh products provided by rural residents to } \\
\text { reach cities, which helps SF expand its market share and } \\
\text { potential consumers."-- Logistics practitioner in BaNiu } \\
\text { Village }\end{array}$ \\
\hline $\begin{array}{l}\text { People at the } \\
\text { bottom of } \\
\text { pyramid }\end{array}$ & $\begin{array}{l}\text { Farmers actively } \\
\text { participate in inclusive } \\
\text { entrepreneurship }\end{array}$ & $\begin{array}{l}\text { "Taobao ecosystem improve the personal skills of those at the } \\
\text { bottom of the pyramid, including communication skills, } \\
\text { business awareness and competence, management and } \\
\text { leadership, can also boost self-esteem."-- Government officer } \\
\text { of ZaoMei Village }\end{array}$ \\
\hline
\end{tabular}

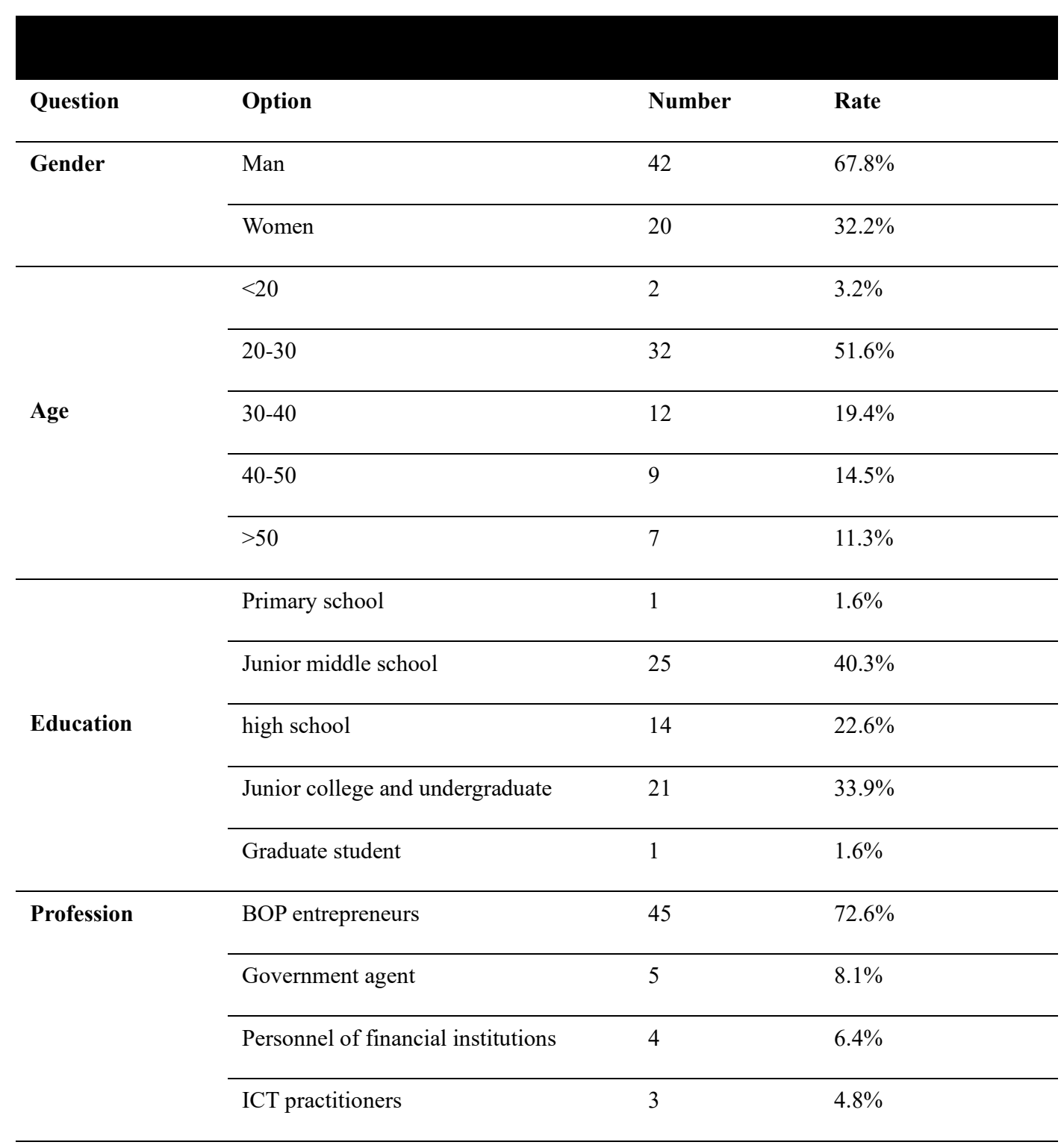




\section{$\begin{array}{lll}\text { Logistics practitioners } & 5 & 8.1 \%\end{array}$}

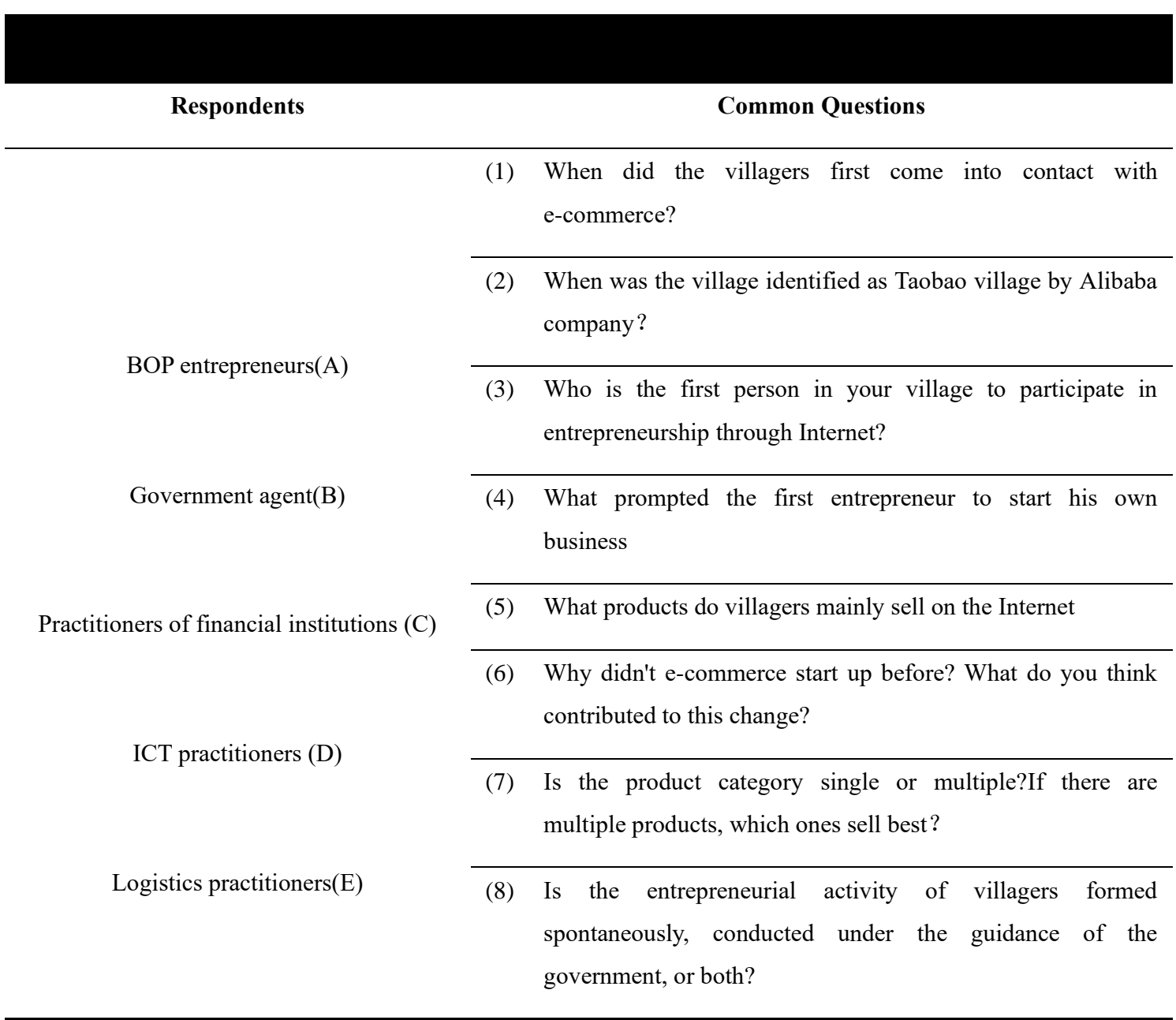

(Notes: according to the job description of each respondent, the concentration of question area might be different. During the interviews, respondents are encouraged to give examples for certain strategies).

(1) How has the number of entrepreneurs increased in your village? 


\begin{tabular}{|c|c|c|}
\hline & (2) & $\begin{array}{l}\text { What do you think is the reason for the new wave of } \\
\text { entrepreneurs? }\end{array}$ \\
\hline BOP entrepreneurs(A) & (3) & $\begin{array}{l}\text { Will the later entrepreneurs choose the same or similar } \\
\text { business model as the previous entrepreneurs? }\end{array}$ \\
\hline Government agent(B) & (4) & $\begin{array}{l}\text { Will the later entrepreneurs learn from the experience of } \\
\text { previous entrepreneurs? }\end{array}$ \\
\hline Practitioners of financial institutions (C) & $(5)$ & $\begin{array}{l}\text { In your opinion, from the appearance of the first entrepreneur } \\
\text { to the development up to now, what stages has your taobao } \\
\text { village gone through? What are the landmarks events? }\end{array}$ \\
\hline ICT practitioners $(\mathrm{D})$ & (6) & $\begin{array}{l}\text { Which actors do you think will join or exit in each stages of } \\
\text { development? What role do they play in each stage? }\end{array}$ \\
\hline \multirow{3}{*}{ Logistics practitioners(E) } & (7) & $\begin{array}{l}\text { Which people in Taobao village do you think are directly or } \\
\text { indirectly involved in e-commerce entrepreneurial activities? }\end{array}$ \\
\hline & (8) & $\begin{array}{l}\text { What do you think of the impact of Taobao village's } \\
\text { entrepreneurial activities on low-income people? What role } \\
\text { can they play in it? }\end{array}$ \\
\hline & (9) & $\begin{array}{l}\text { What factors do you think are driving the continuous } \\
\text { development of Your Taobao village }\end{array}$ \\
\hline
\end{tabular}

Table A3. Semi-structured interview protocol (Second round)

(Notes: according to the job description of each respondent, the concentration of question area might be different. During the interviews, respondents are encouraged to give examples for certain strategies).

\begin{tabular}{|c|c|c|}
\hline Respondents & Question & $\begin{array}{l}\text { Common Questions } \\
\text { (1) What factors do } \\
\text { you think will affect } \\
\text { the success of } \\
\text { entrepreneurship of } \\
\text { the people at the } \\
\text { bottom of the } \\
\text { pyramid? } \\
\text { (2)Do you think that } \\
\text { the entrepreneurial } \\
\text { ecosystem of Taobao } \\
\text { village in China is } \\
\text { composed of }\end{array}$ \\
\hline \multirow{4}{*}{$\begin{array}{l}\text { BOP } \\
\text { entrepreneurs }\end{array}$} & What is your motivation for entrepreneur? & \multirow{5}{*}{$\begin{array}{l}\text { (1) What factors do } \\
\text { you think will affect } \\
\text { the success of } \\
\text { entrepreneurship of } \\
\text { the people at the } \\
\text { bottom of the } \\
\text { pyramid? } \\
\text { (2)Do you think that } \\
\text { the entrepreneurial } \\
\text { ecosystem of Taobao } \\
\text { village in China is } \\
\text { composed of }\end{array}$} \\
\hline & $\begin{array}{l}\text { - What is the biggest obstacle you encounter in the } \\
\text { process of entrepreneurship? Is it solved? How to solve it? }\end{array}$ & \\
\hline & $\begin{array}{l}\text { - Do you get help from others when you start } \\
\text { entrepreneurship? What are the main aspects? }\end{array}$ & \\
\hline & $\begin{array}{l}-\quad \text { What are the key factors that determine the success } \\
\text { or failure of a entrepreneu? }\end{array}$ & \\
\hline $\begin{array}{l}\text { Government } \\
\text { agent }\end{array}$ & $\begin{array}{l}\text { - How does your organization support the } \\
\text { entrepreneurial projects of the people at the bottom of the } \\
\text { pyramid? }\end{array}$ & \\
\hline
\end{tabular}




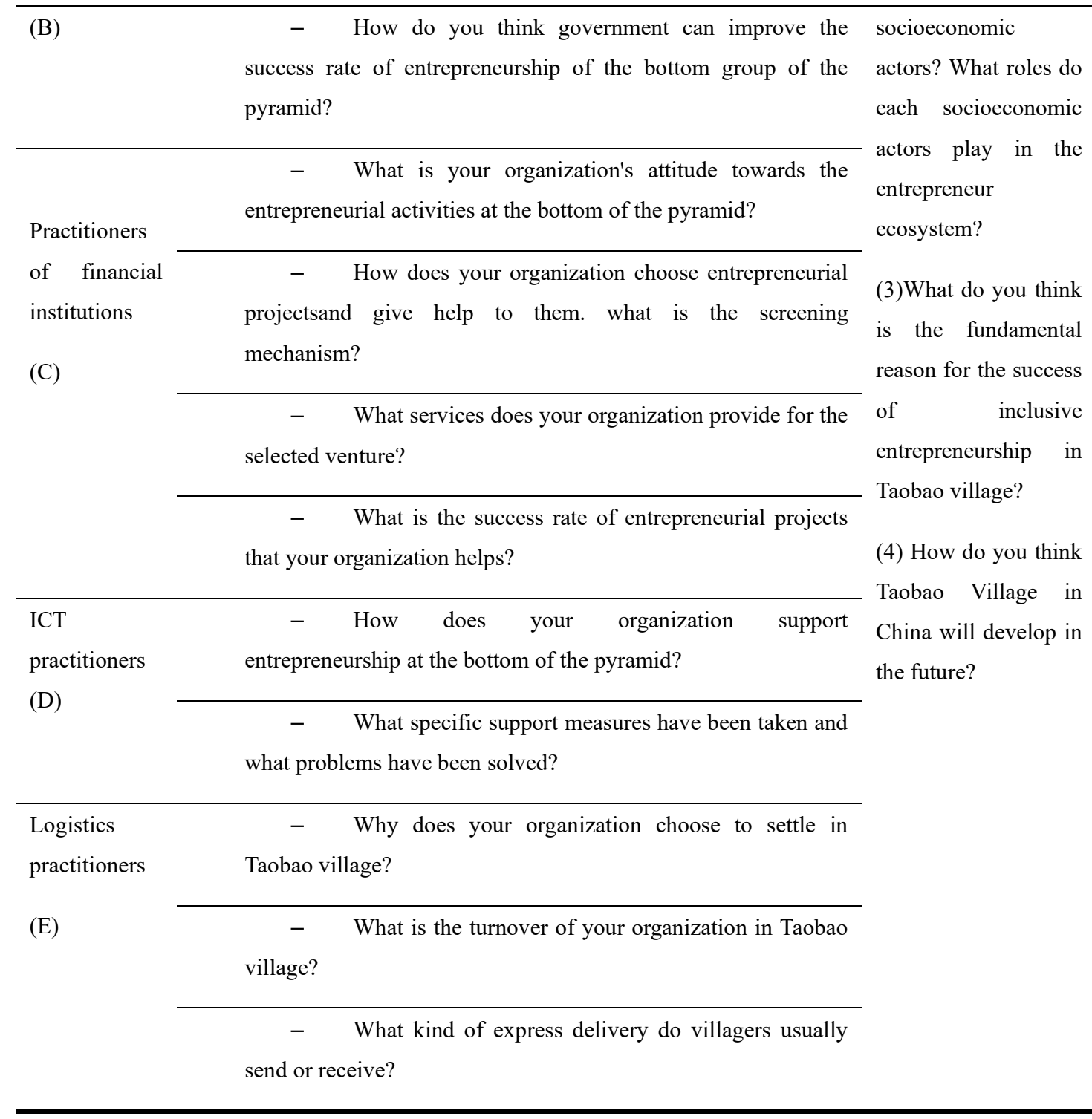

Table A4. Semi-structured interview protocol (Third round)

(Notes: according to the job description of each respondent, the concentration of question area might be different. During the interviews, respondents are encouraged to give examples for certain strategies). 


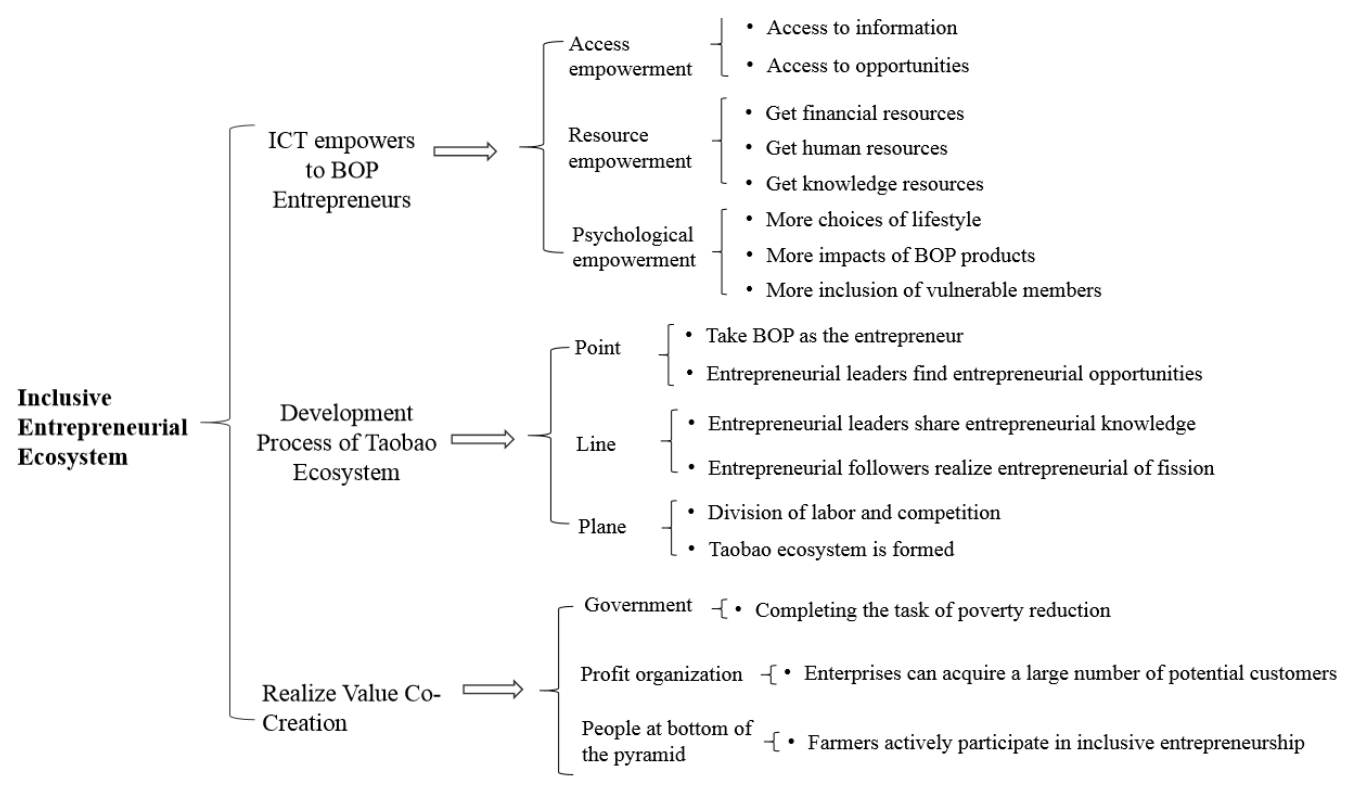

Figure A1. Coding schemes. 